\title{
Analysis of Fatigue and Crack Growth in Carbon-Fiber Epoxy Matrix Composite Laminates
}

\author{
S. Putić, P. S. Uskoković, and R. Aleksić \\ Faculty of Technology and Metallurgy, Belgrade, Yugoslavia
}

удК 539.4

\begin{abstract}
Анализ усталостного разрушения и роста трещин в ламинатных композитах с эпоксидной матрицей, армированных графитовыми волокнами
\end{abstract}

\section{С. Путич, П. С. Ускокович, Р. Алексич}

Факультет технологии и металлургии, Белград, Югославия

\begin{abstract}
Выполнены высокочастотные усталостные испытания композитных материалов, армированных графитовыми волокнами. Проведен сравнительный анализ усталостного поведения графитоэпоксидных ламинатных материалов с надрезом и без надреза для различных случаев ориентации волокон $\left(0^{\circ} / 90^{\circ}\right.$ и $\left.\pm 45^{\circ}\right)$. Кроме того, с приленением метода сканирующей электронной микроскопии осуществлен микромеханический анализ поверхностей разрушения с иелью обнаружения микромеханизмов разруиения материала. Полученные экспериментальныле результать показали, что усталостное повреждение обусловлено комбинированныли эффектами трецинообразования в матрице, продольного расслоения, разрушения волокон и деламинации. Для минимизирования остаточных деформационньхх эффектов, связанных с повышением температуры, предложен метод определения фактической усталостной прочности как переменного уровня нагрузки не ниже предела усталостной прочности, при котором имеют место минилальные остаточные напряжения.
\end{abstract}

Ключевые слова: усталость, ламинатные композиты, кривая усталости $S-N$, рост трещины.

Introduction. Fatigue behavior of composite materials has been the subject of intense research in recent years since fatigue is known to be responsible for the majority of failures of structural components. Local damage in isotropic materials, such as metals and polymers, usually develops monotonically leading to material failure. In composite materials, on the contrary, a combination of four main damage modes has been observed under fatigue loading, namely, matrix cracking, fiber-matrix debonding, delamination, and fiber fracture. Carbon-fiber reinforced polymer (CFRP) composites are attractive in that they combine high strength, high modulus, and low density. Among many studies regarding CFRPs, some were concerned with their fatigue behavior. For instance, Miyano et al. [1] carried out fatigue tests of unidirectional CFRPs at various temperatures and loading rates. Harris et al. [2] observed for angleply CFRPs that the combination of tensile and compressive fatigue loading is more damaging than purely tensile or compressive stress cycling. Wang and Chung [3] achieved self-monitoring of

(C) S. PUTIĆ, P. S. USKOKOVIĆ, R. ALEKSIĆ, 2003

ISSN 0556-171Х. Проблемы прочности, 2003, № 5 
fatigue damage in a crossply CFRP by electrical resistance measurement. Studies were engaged in comparison of tensile fatigue behavior of unidirectional [4] and quasi-isotropic [5] CFRPs with thermoplastic and thermosetting matrices. By using a thorough fractographic analysis, Shin and Jang [6] investigated delamination features in woven CFRPs.

The influence of the material properties, processing conditions, and design on the resulting fatigue performance of composites invalidates any generalization of the experimental results for nominally identical composites [7]. Since coupon specimens are sensitive to the free edge effects, they seem more susceptible to fatigue damage than the entire structure. Although more desirable, testing of a complete structural part is costly, complicated, and not easy to standardize, which leaves coupon specimen testing still in use for its simplicity and ease. Curtis et al. [8] surmise that low-frequency fatigue experiments, in which a particular material response is recorded, might provide a better depiction of the component performance than higher frequency laboratory tests. In fatigue tests at higher frequencies, the material of a structure may be subjected to a more complex stress state than in an idealized coupon. However, the necessity for defining suitable tests at a coupon-level, which could be used as a part of the methodology for a reliable fatigue design, leads to a need for high-frequency fatigue tests. The literature recognizes the possibility of temperature rise during fatigue of composites that depends primarily on the level and frequency of cyclic load and can be attributed to a number of various heat sources [8-11]. This study characterizes the high-frequency fatigue behavior of a crossply and angleply carbon-fiber reinforced epoxy by $S-N$ testing and by analysis of crack growth. In order to minimize the effect of residual strains due to temperature rise, which may disturb fatigue measurements, we propose a method for determining a more realistic value of the fatigue strength designated in this study as the real fatigue strength.

Overview of Materials and Performed Experiments. Sixty-seven specimens were fabricated by using unidirectional carbon-epoxy prepregs (Brochier), which had the thickness of a single layer of approximately $0.15 \mathrm{~mm}$ with two arrangements of reinforcements $\left(0^{\circ} / 90^{\circ}\right.$ and $\left.\pm 45^{\circ}\right)$. The specimens were manufactured in an autoclave according to the manufacturer's recommendations at $175^{\circ} \mathrm{C}$ and 7 bar for 1 hour followed by $190^{\circ} \mathrm{C}$ and 7 bar for 4 hours. Finally, the specimens were cooled slowly down to $40^{\circ} \mathrm{C}$. The fraction of the fiber mass for each specimen was approximately $65 \%$. Depending on the type of investigation and the corresponding standard, various specimen dimensions were used. A review of the investigations with designations of the specimen series used is presented in Table 1.

Static tensile tests were performed on a servo-hydraulic testing machine (Schenck Trebel RM 100) with hydraulic grips. The mean values of the tensile strength and modulus of elasticity were determined for specimens Z-1 and found to be $503.6 \mathrm{MPa}$ and $47.4 \mathrm{GPa}$, respectively, while the shear strength and modulus for specimens S-2 were $102 \mathrm{MPa}$ and $5.4 \mathrm{GPa}$, respectively.

The investigations of fatigue strength were performed at a tensile variable load on a high-frequency pulsator (Amsler), which can develop sinusoidal variable loads in the range from -100 to $+100 \mathrm{kN}$. Mean values of the load and 
load amplitude were registered with an accuracy of $\pm 50 \mathrm{~N}$. The stress ratio in fatigue was 0.1 , and the frequency was in the range from 120 to $130 \mathrm{~Hz}$. For the purpose of residual strain measurements, strain gauges were glued to the specimens and connected to a PC through a multi-channel dynamic record system (Alpha 2000) with a converter. The level of residual strains was registered in relation to the number of cycles. Specimens from series TD-1, TD-2, SD-1, and SD-2 were waisted to a minimum width of $20 \mathrm{~mm}$ with a radius of $34 \mathrm{~mm}$.

$\mathrm{T}$ a b 1 e 1

Program of Investigations with Specimen Series Dimensions and Designations

\begin{tabular}{|c|c|c|c|c|c|}
\hline \multirow[t]{2}{*}{ Determined properties } & \multicolumn{2}{|c|}{ Lay-up } & \multirow{2}{*}{$\begin{array}{l}\text { Dimensions } \\
(\mathrm{mm})\end{array}$} & \multirow{2}{*}{$\begin{array}{l}\text { Number } \\
\text { of layers }\end{array}$} & \multirow{2}{*}{$\begin{array}{c}\text { Number } \\
\text { of specimens }\end{array}$} \\
\hline & $0^{\circ} / 90^{\circ}$ & $\pm 45^{\circ}$ & & & \\
\hline Static tensile properties & $\mathrm{Z}-1$ & - & $250 \times 20 \times 2.5$ & 20 & 10 \\
\hline Static shear properties & - & $\mathrm{S}-2$ & $250 \times 30 \times 3$ & 24 & 10 \\
\hline Fatigue strength & TD-1 & TD-2 & $140 \times 30 \times 2$ & 16 & $15+18$ \\
\hline Real fatigue strength & SD-1 & $\mathrm{SD}-2$ & $140 \times 30 \times 2$ & 16 & $4+4$ \\
\hline Fatigue crack growth & DA-1 & DA-2 & $55 \times 10 \times 8$ & 64 & $3+3$ \\
\hline
\end{tabular}

Tests for determining the crack growth rate were carried out on a resonant high-frequency pulsator (Cracktronic) in three-point bending. The testing machine can produce a sinusoidal discontinuous moment within the range from -70 to $+70 \mathrm{~N} \cdot \mathrm{m}$. The experiments were performed with the force control at the same stress ratio of 0.1 and with the dynamic moment varying within the range from 12.7 to $4.4 \mathrm{~N} \cdot \mathrm{m}$. The frequency ranged from 132 to $155 \mathrm{~Hz}$. Subsize Charpy specimens (Fig. 1) were cut by a hard-metal milling cutter from small bars extracted from panel samples. Series of three specimens from each lay-up were mechanically prepared before the test and taped with crack gauge foil (Rumul RMF A-5) glued like a common strain gauge for recording the growth of a fatigue crack.

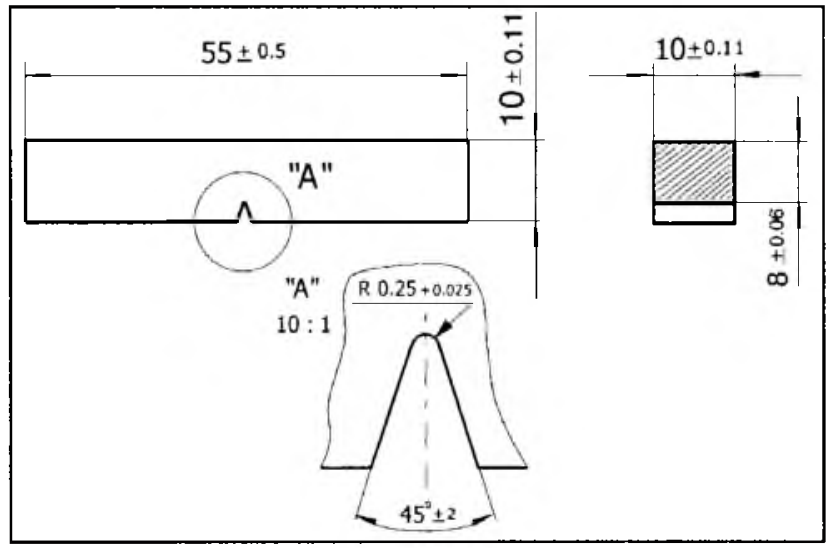

Fig. 1. Geometry and dimensions of a modified Charpy specimen. 
Fracture surfaces of mechanically fractured specimens were analyzed by scanning electron microscopy (Philips-SEM 525) to study micromechanisms of fatigue. The fracture surfaces were vapor-coated with a thin layer of gold to enhance the quality of the image.

Fatigue Strength. The results obtained for specimens selected from the series of two lay-ups are presented in the form of $S-N$ curves in Fig. 2. During the experiment, it was established that the stress amplitude $S$ decreased continuously with increasing number of cycles $N$. Fatigue strength $S_{f}$ was defined as the strength after $10^{7}$ cycles. By comparing these results with those obtained for woven glass-epoxy laminates with the same stacking sequence [12, 13], one can see that the $S-N$ curves for both TD-1 and TD-2 specimen series are rather flat, meaning that slight changes in the stress level resulted in big differences in the cycles. The flatness of the curves was expected since the carbon-epoxy laminate tested has a fiber-dominated strength. The obtained values of $S_{f}$ were $425 \mathrm{MPa}$ and $95 \mathrm{MPa}$ for TD-1 and TD-2, respectively. Higher values were found for the $0^{\circ} / 90^{\circ}$ orientation, which is probably due to the dominant shear-stress components for $\pm 45^{\circ}$ orientation, and the fact that the lay-ups containing $\pm 45^{\circ}$ fibers have no fibers along the load direction [14]. The values of the fatigue strength obtained for all tested specimens were in the range from 80 to $90 \%$ of the static strength value.

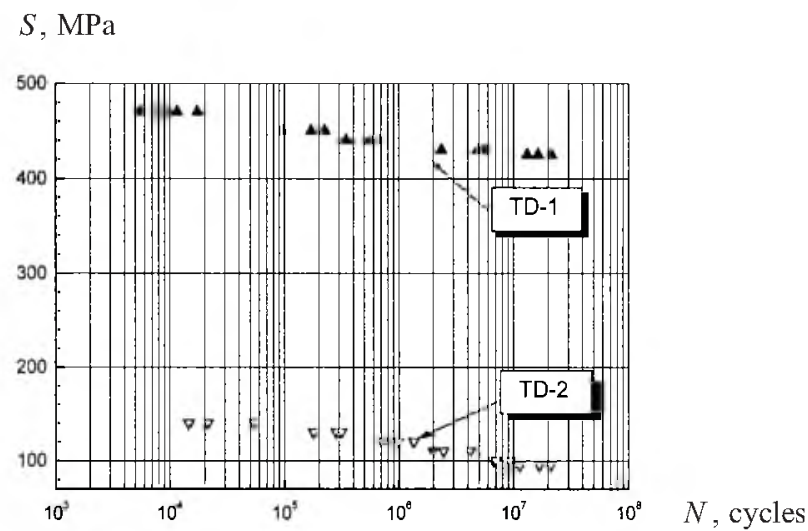

Fig. 2. Comparative presentation of $S-N$ curves for specimen series of $0^{\circ} / 90^{\circ}$ and $\pm 45^{\circ}$ orientations.

Real Fatigue Strength and Residual Strain. Due to the resin matrix viscoelasticity, as well as to the ply failure and delamination [8], the dissipation of heat manifested through the temperature increase can develop within the material during fatigue. As a consequence, the matrix degrades in spite of the fact that a thermosetting matrix with a melting point of about $190^{\circ} \mathrm{C}$ was utilized. If the matrix contribution to the load-carrying capacity is not negligible, the matrix softening caused by the temperature increase will apparently degrade the fatigue strength. Joseph and Perreux [11] pointed out that low frequencies induce an additional damage mechanism most likely due to creep, which is attenuated as the frequency increases. On the other hand, when high frequencies are imposed, the 
material degradation rate increases with temperature. Unfortunately, this process is not easily predictable since it depends on the specimen geometry and size, test waveform (amplitude and frequency), and features such as the type of matrix and friction between the matrix and fibers.

In order to partially shield the effects of these phenomena, investigations were performed with the aim to register residual strains $\varepsilon$ and to determine the levels of the variable load at which residual strains are the lowest but are not below the fatigue limit. The dependence of the residual strain on the number of cycles at various variable load levels is presented in Fig. 3a and b. The values of the variable load at which residual strains are minimal were determined from the obtained dependencies and were designated as the real fatigue strength $S_{f r}$ (Table 2). Its significance is in that the influence of the thermal effect, which may disturb the fatigue measurement, is minimized.

$\mathrm{T}$ a b 1 e 2

The Determined Values of the Real Fatigue Strength and Residual Strain

\begin{tabular}{|c|c|c|}
\hline Specimen series & Residual strain $\varepsilon, \mu \mathrm{m} / \mathrm{m}$ & Real fatigue strength $S_{f r}, \mathrm{MPa}$ \\
\hline SD-1 & 727 & 418 \\
SD-2 & 569 & 90 \\
\hline
\end{tabular}

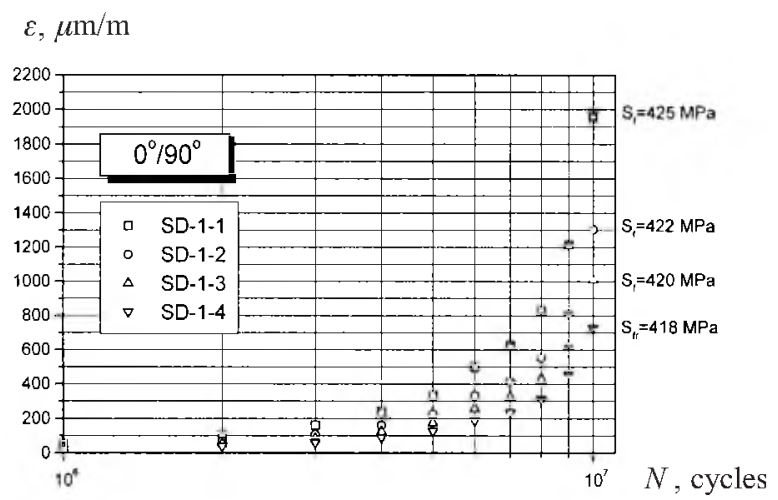

a

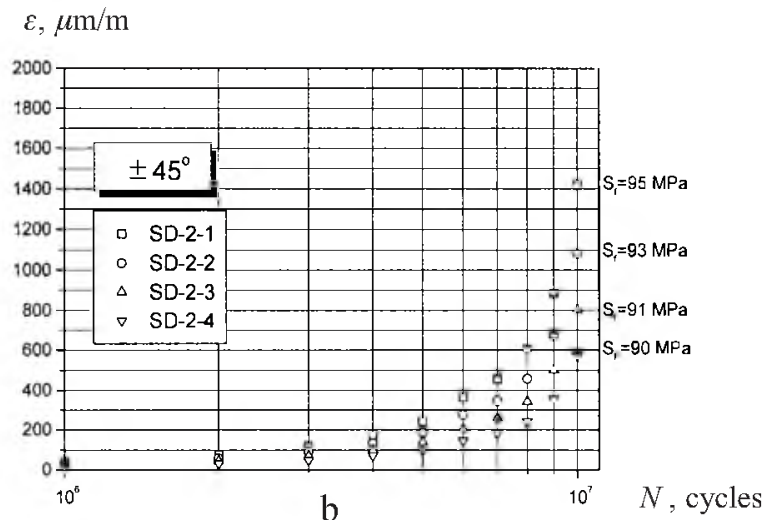

Fig. 3. Dependence of residual strain on the number of cycles at various load levels: (a) for specimens of the SD-1 series; (b) for specimens of the SD-2 series. 
Micromechanical Analysis of the Fatigue Crack Growth. In composites, unlike isotropic materials, microcracks are initiated at an early stage of loading but composites still can stand the load until final fracture. In real service, damage is a complex mixture of transverse cracks, splits, fiber fractures, and delamination. Analyzing damage growth is rather difficult, but fracture mechanics approaches are an option when the growth of damage is presented by the progression of a single crack such as delamination. The crack density can be considered as a single distributed damage, and it may be studied by fracture mechanics as a single crack through different approaches.

The crack growth measurements (crack length, $a$, against the number of fatigue cycles, $N$ ) allow determination of the slopes $d a / d N$ from the graphs. During the investigation, the number of cycles for every $0.05 \mathrm{~mm}$ of the crack length was recorded and then $a$ vs $N$ diagrams were plotted. Figure 4 shows characteristic $a$ vs $N$ diagrams for both lay-ups tested. Similar trends were observed for other two tested specimens from each configuration series. It is obvious that at the same load level, the number of cycles required for crack formation for DA-1-1 $\left(0 / 90^{\circ}\right)$ specimens is larger than that for DA-2-1 $\left( \pm 45^{\circ}\right)$ specimens. This conclusion can be related to the mechanical characteristics of the respective configuration, i.e., the specimen with a higher tensile strength shows a higher resistance to crack formation. Also, for the DA-1-1 specimen, the $a$ vs $N$ curve has an abrupt shift from the linear portion indicating an increase in the crack growth rate. In this case, for the same crack length increment, a considerably smaller number of cycles is required than that for the initial crack formation. In the DA-2-1 case, this shift is more gradual.

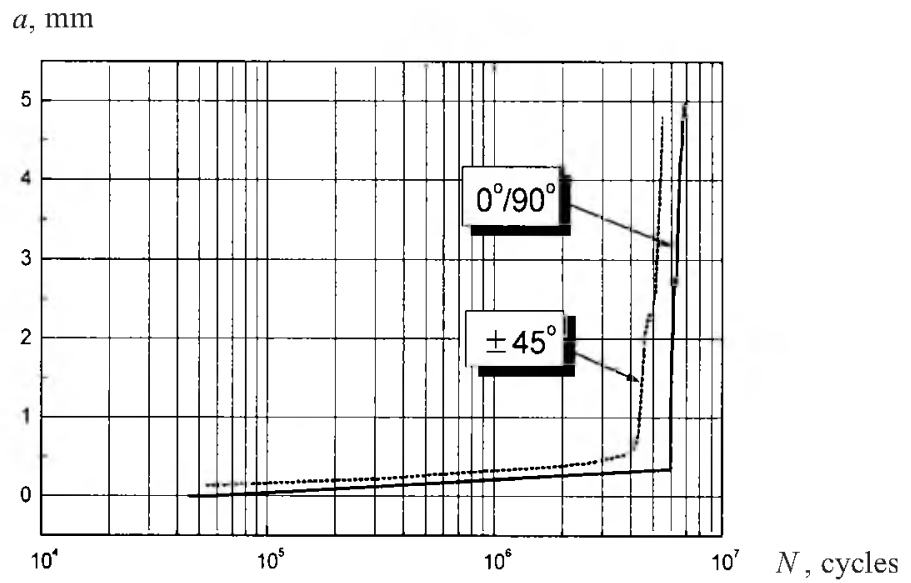

Fig. 4. Fatigue crack growth versus the number of cycles.

These $a$ vs $N$ diagrams served as a basis for calculating the crack growth rate $d a / d N$. Because of the large number of data compiled during testing of one specimen (about 50 measurements), the ratio $d a / d N=\log (\Delta K)$ is generally presented graphically (Fig. 5). Depending on the range of the stress intensity factor $\Delta K$, the coefficient $C$ and exponent $n$ were calculated from the Paris law [15]: 


$$
d a / d N=C(\Delta K)^{n} .
$$

Figure 5 shows the lower limit to damage growth, or the effective no-growth threshold, which forms the basis of many current design approaches. The higher value of the fatigue threshold $\Delta K_{t h}$ was found for specimen DA-1-1. It also has the lower crack growth rate $d a / d N$. This can be seen by comparing the $d a / d N$ vs $\Delta K$ diagrams, where the slope of the portion of the curve where the Paris law is valid is greater in the case of specimens that have a lower crack growth rate. This conclusion can also be confirmed by the corresponding values of the stress intensity factor range $\Delta K$, because from the diagram it is obvious that a larger range of the stress intensity factor $\Delta K$ is registered for the same value of $d a / d N$. As opposed to DA-1-1 specimen, in the case of DA-2-1 specimen, one can notice the higher crack growth rate and relatively low values of the fatigue threshold, which confirms the fact that there are exceptionally high shearing interlaminar stresses in such structures that weaken the construction. The observed differences occurred due to various crack growth micromechanisms.

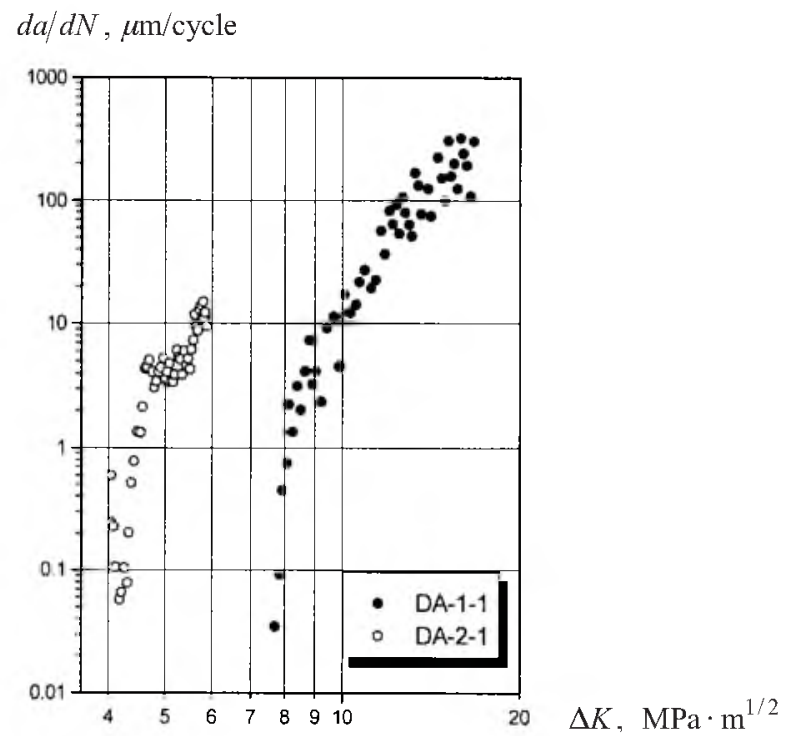

Fig. 5. Measured constant-amplitude fatigue crack growth curves for DA-1 and DA-2 lay-ups with thresholds at $\Delta K_{t h}=7.7$ and $4.1 \mathrm{MPa} \cdot \mathrm{m}^{1 / 2}$, respectively.

Fractography. In order to explain the mechanism of the fatigue fracture events observed, scanning electron microscopy (SEM) was used to study the fracture surfaces of specimens after fatigue testing. Micromechanically, voids or stress concentrations in the matrix are normally the points of initiation of cracking. For the case of TD-1 type specimens, transverse cracking immediately occurred in the $90^{\circ}$ layers, and during subsequent cycling, lead to crack formation in the matrix in the layers with $0^{\circ}$ orientation, as shown in Fig. 6. The complex stress state around the crack tip caused crack formation in the matrix and high stress concentrations in the layers with $0^{\circ}$ orientations. This leads to fiber-matrix debonding, delamination, and fiber breakage. Fracture of the composite occurred 
at the moment when it was weakened by longitudinal cracks and cracks formed by delamination of the layers with opposite orientations, which enabled proper stress transfer between them. The fiber breakage within the weakest layer was followed by progressive failure of the fibers in remaining layers. Delamination of the layers with opposite fiber orientations near the fracture surface and a region of higher magnification can be observed in Fig. 7. In general, the sequence of damage in composites observed in fractographic studies of the fracture surfaces of specimens subjected to $a-N$ testing agreed with the previous ones and with the investigations on the damage mechanisms of crossply glass-epoxy laminates [16], revealing that the growth of the main crack was a result of successive breakage of fibers in lay-ups containing $0^{\circ}$ fibers. In bending fatigue, a crack normal to the $0^{\circ}$ layers is introduced by the notch, while in tensile fatigue, the initial crack is normal to the loading direction $\left(0^{\circ}\right)$, i.e., normal to the tensile stress.

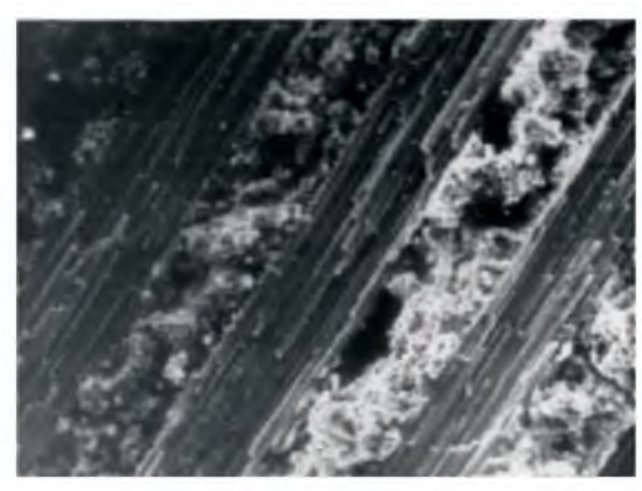

Fig. 6

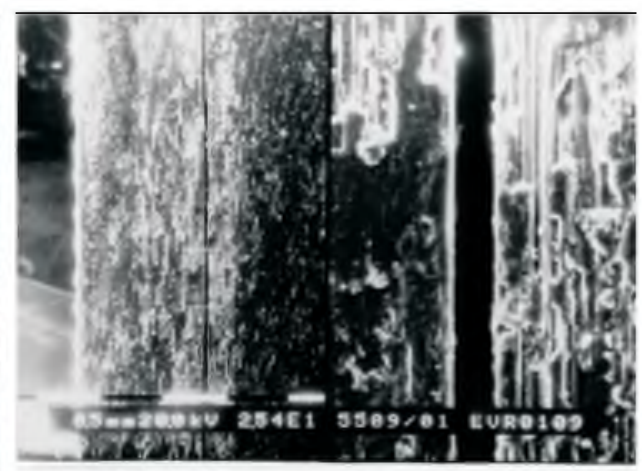

Fig. 7

Fig. 6. SEM micrograph of the fracture surface of TD-1 specimen showing matrix cracking in $0^{\circ}$ layers.

Fig. 7. SEM micrograph of the fracture surface of TD-1 specimen showing progressive delamination between layers of opposite orientation (left: $\times 25.4$ magnification; right: detailed view of delamination).

In the case of crossply specimens, failure resulted from breakage of the majority of fibers in the layers and from macroscopically visual fiber pullout from the matrix. This was accompanied by delamination, which represents the additional phenomenon of failure during fatigue loading. The initial cracks started in the matrix of one layer and, after a certain number of cycles, they transformed into a macrocrack as a result of saturation. The appearance of such a crack caused a complex stress state, which was transferred by shear stresses to the neighboring layers of opposite orientation. The crack spreading along the fibers weakened the fiber-matrix bond; as a result, the entire load was transferred to fibers that lead to their failure (Fig. 8). Similar mechanism of fatigue damage growth was found in $a-N$ tested specimens. The main difference is in the fact that subcritical cracks were growing at the same time in lay-ups containing $+45^{\circ}$ and $-45^{\circ}$ fibers. Also, unstable direction of the main crack growth was observed, which is reasonable having in mind that the fiber breakage occurred in different locations but always at approximately $45^{\circ}$ to the tensile axis. 


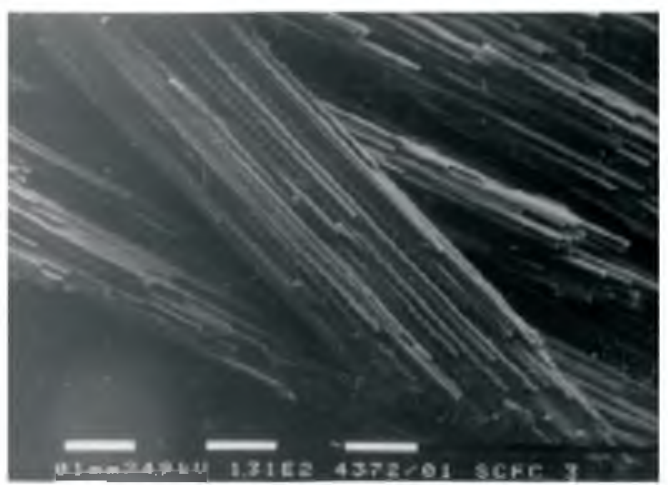

Fig. 8. SEM micrograph of the fracture surface of TD-2 specimen showing fiber breakage in the layers.

Crack paths are highly complex, and the crack itself is not the only manifestation of structural damage. Matrix cracks, fiber breakage, fiber/matrix splitting, and debonding between the laminate layers could aid the degradation of the composite's mechanical properties. Furthermore, this damage may be widespread and not necessarily localized in the crack-tip region, although this is usually where the damage is most severe.

During operation, composites are subjected to repeating and fluctuating stresses, which implies that, for successful application, designers must be convinced of the long-term durability and reliability of composites. Although significant efforts on fatigue characterization of CFRPs have been made, there is still a need for experimental data required for a complete view of the composite response to the applied cyclic loading.

Conclusions. The values of fatigue strength obtained for both orientations were in the range of $80-90 \%$ of the degree of the static strength with higher values found for the $0^{\circ} / 90^{\circ}$ orientation. The difference in the fatigue strength between the lay-ups is significant, confirming that the fatigue strength is mainly dependent on the fiber properties. The lay-ups containing $45^{\circ}$ fibers have a much lower fatigue strength since they have no fibers along the load direction.

In the case where fatigue tests at higher frequencies are necessary for the generation of fatigue design data, a method is proposed for determining a real fatigue strength as a variable load level at which residual strains are minimal, although still higher than the fatigue limit.

As opposed to crossply specimens, in the case of angleply specimens, the high crack growth rate and relatively low values of the fatigue threshold were recorded. This confirms the fact that in such structures, high shearing interlaminar stresses contribute to additional weakening of the construction.

Fractographic analysis revealed that transverse cracking immediately occurred in the $90^{\circ}$ layers of the crossply specimens. As a consequence, significant matrix cracks occurred in $0^{\circ}$ layers, and after saturation, there followed delamination of the layers of opposite orientation or longitudinal fiber-matrix splitting and subsequent fiber breakage. In the case of angleply specimens, the initial crack started in the matrix of one layer and developed until the breakage of the majority of fibers in the layers accompanied by delamination. 


\section{P ез о м е}

Виконано високочастотні випробування на втому композитних матеріалів, що армовані гафітовими волокнами. Проведено порівняльний аналіз поведінки графітоепоксидних ламінатних матеріалів із надрізом та без від утоми для різних випадків орієнтаціїі волокон $\left(0^{\circ} / 90^{\circ}\right.$ і $\left.\pm 45^{\circ}\right)$. Окрім того, 3 використанням методу сканувальної електронної мікроскопії виконано мікромеханічний аналіз поверхонь руйнування 3 метою виявлення мікромеханізмів руйнування матеріалу. Отримані експериментальні дані показали, що пошкодження від утомленості зумовлено комбінованими ефектами тріщиноутворення в матриці, поздовжнього розшарування, руйнування волокон та деламінації. Для мінімізації залишкових деформаційних ефектів, пов'язаних iз підвищенням температури, запропоновано метод визначення фактичної міцності від утомленості як змінного рівня навантаження не нижче границі міцності від утомленості, за якої мають місце мінімальні залишкові напруження.

1. Y. Miyano, M. Nakada, H. Kudoh, and R. Muki, "Prediction of tensile fatigue life for unidirectional CFRPs," J. Compos. Mater., 34, 538-550 (2000).

2. B. Harris, N. Gathercole, H. Reiter, and T. Adam, "Fatigue of carbon-fiber reinforced plastics under block-loading conditions," Compos., Part A, Appl. S., 28A, 327-337 (1997).

3. X. Wang and D. D. L. Chung, "Self-monitoring of fatigue damage and dynamic strain in carbon-fiber polymer-matrix composite," Compos., Part B, Eng., 29B, 63-73 (1998).

4. E. K. Gamstedt and R. Talreja, "Fatigue damage mechanisms in unidirectional carbon-fiber reinforced plastics," J. Mater. Sci., 34, 25352546 (1999).

5. F. Aymerich and M. S. Found, "Response of notched carbon/PEEK and carbon/epoxy laminates subjected to tensile fatigue loading," Fatigue Fract. Eng. Mech., 23, 675-683 (2000).

6. S. Shin and J. Jang, "Fractographic analysis on the mode II delamination in woven carbon-fiber reinforced epoxy composites," J. Mater. Sci., 34, 52995306 (1999).

7. O. Konur and F. L. Matthews, "Effect of the properties of the constituents on the fatigue performance of composites: A review," Composites, 20, 317-328 (1989).

8. D. C. Curtis, D. R. Moore, B. Slater, and N. Zahlan, "Fatigue testing of multi-angle laminates of CF/PEEK," Composites, 19, 446-452 (1988).

9. J. W. Dally and L. J. Broutman, "Frequency effects on the fatigue of glass-reinforced plastics," J. Compos. Mater., 1, 424-442 (1967).

10. H. T. Hahn and R. Y. Kim, "Fatigue behavior of composite laminates," $J$. Compos. Mater., 10, 156-180 (1976). 
11. E. Joseph and D. Perreux, "Fatigue behavior of glass-fiber/epoxy-matrix filament-wound pipes: tensile loading tests and results," Compos. Sci. Technol., 52, 469-480 (1994).

12. S. Putić, "The analysis of fatigue crack growth in glass/epoxy composites," Int. J. Fracture, 85, L27-L31 (1997).

13. S. Putić, R. Aleksić, and P. Uskoković, "Dynamic mechanical behavior of glass-fiber reinforced composites," Mobil. Vehicl. Mech., 25, 59-67 (1999).

14. K. P. Dyer and D. H. Isaac, "Fatigue behavior of continuous glass-fiber reinforced composites," Compos., Part B, Eng., 29B, 725-733 (1998).

15. P. C. Paris and F. Erdogan, "A critical analysis of crack propagation laws," $J$. Basic. Eng., Trans. ASME, 85, 528-534 (1963).

16. J. F. Mandell and U. Meier, "Fatigue crack propagation in $0^{\circ} / 90^{\circ} \mathrm{E}$-glass/ epoxy composites," in: Fatigue of Composite Materials, ASTM STP 569 (1975), pp. 28-44. 